\title{
PENGGUNAAN HAND SANITIZER TERHADAP KEPATUHAN REMAJA MENCUCI TANGAN DI KELURAHAN LUBUK PAKAM PEKAN
}

\section{Pitriani $^{1 *}$, Juni Mariati ${ }^{1}$, Samuel Ginting ${ }^{1}$, Satriawati ${ }^{1}$. Epfik Fantanti Jawak ${ }^{1}$, Luci Riani Ginting ${ }^{2}$}

\author{
${ }^{1}$ Program Studi S1 Keperawatan, Institut Kesehatan Medistra Lubuk Pakam \\ ${ }^{2}$ Program Studi S1 Kesehatan Masyarakat, Institut Kesehatan Lubuk Pakam \\ JIn. Sudirman No.38 Lubuk Pakam, Kabupaten Deli Serdang, \\ Sumatera Utara - Indonesia \\ *email korespondensi author: anipitri663@gmail.com
}

DOI $10.35451 /$ jpk.v1i1.753

\begin{abstract}
Mencuci tangan merupakan proses yang secara mekanik melepaskan kotoran dan debris dari kulit tangan dengan menggunakan sabun biasa dan air. Tujuan pengabdian masyarakat ini untuk penggunaan hand sanitizer terhadap kepatuhan remaja mencuci tangan. Metode pengabdian masyarakat menggunakan Bentuk penelitian preeksperimental ini dilaksanakan dengan rancangan one-group pretest-posttest design yang mana pada desain ini terdapat pretest (sebelum diberi perlakuan). Populasi dari pengabdian masyarakat ini sejumlah 41 remaja dengan tehnik sampling menggunakan total sampling. Hasil pengabdian masyarakat berdasarkan hasil analisis dari Uji Paired $T$-test diperoleh $p$-value $=0.000<a=0,05$, dapat disimpulkan bahwa masih ada penggunaan hand sanitizer terhadap kepatuhan cuci tangan di kelurahan lubuk pakam pekan. Kesimpulan: remaja melakukan cuci tangan menggunakan hand sanitizer selesainya hubungan langsung dengan orang asing buat mencegah terjadinya infeksi silang virus covid 19.
\end{abstract}

Keywords: hand sanitizer, remaja, mencuci tangan

\begin{abstract}
Hand washing is a process that mechanically removes dirt and debris from the skin of the hands using plain soap and water. The purpose of this community service is to use hand sanitizers for adolescent compliance with washing hands. The community service method uses this form of pre-experimental research carried out with a one-group pretest-posttest design in which there is a pretest (before treatment). The population of this community service is 41 teenagers with a sampling technique using total sampling. The results of community service based on the results of the analysis of the Paired $T$-test obtained $p$-value $=0.000<a=0.05$, then the hypothesis is accepted, so it can be concluded that there is the use of hand sanitizers on hand washing compliance in Lubuk Pakam weekend. Conclusion: teenagers wash their hands using hand sanitizer after direct contact with strangers to prevent cross-infection with the covid 19 virus.
\end{abstract}

Keyword: hand sanitizer, youth, washing hands 
Received: 16 June 2021 :: Accepted: 23 June 2021 :: Published: 30 June 2021

\section{Pendahuluan}

Mencuci tangan merupakan salah satu kegiatan yang wajib dilakukan terlebih selama pandemi COVID-19. Berbagai ahli menyatakan bila rutin mencuci tangan menggunakan sabun \& air mengalir merupakan cara yg paling efektif buat membasmi kuman ataupun virus. Hand sanitizer menjadi alternatif buat mencuci tangan yang bisa diandalkan. Hand sanitizer adalah salah satu bahan antiseptic berupa gel yg tak jarang digunakan sebagai media pencuci tangan yang praktis. Bagi sebagian rakyat mencuci tangan menggunakan hand sanitizer lebih efektif dan efisien dibanding mencuci tangan dengan sabun dan air. (Fauztihana, 2020).

Praktek cuci tangan oleh perawat yang direkomendasikan adalah mencuci tangan 6 langkah dan lima moment. Masalah ini menjadi perhatian dunia karena terjadinya peningkatan kejadian infeksi yang terjadi di rumah sakit dan di masyarakat. Berdasarkan data dari CDC (Centers for Disease Control and Prevention) tahun 2015 sebanyak 722.000 kasus HAIs dalam setahun dan 75.000 kasus infeksi yang disebabkan oleh kurangnya kesadaran untuk mencuci tangan. Diperkirakan 70\% tenaga kesehatan dan $50 \%$ tim kesehatan tidak melakukan cuci tangan secara rutin. Beberapa hasil penelitian menunjukkan bahwa cuci tangan efektif untuk menurunkan infeksi nosokomial (Depkes, 2015).

Tingkat infeksi yang terjadi di beberapa negara Eropa dan Amerika masih sangat rendah yaitu sekitar $19 \%$ dibandingkan dengan kejadian di negara-negara Asia, Amerika Latin, Afrika yang tinggi hingga mencapai lebih dari $40 \%$ dan menurut WHO, angka kejadian infeksi di RS di negaranegara Asia sekitar 3-21\% (rata-rata 9\%) (Depkes RI, 2010). Jumlah infeksi nosokomial di Indonesia dalam tahun 2006 lebih tinggi pada Rumah Sakit umum 23.223 menurut 2.434.26 pasien. Sedangkan jumlah infeksi pada Rumah Sakit spesifik 297 pasien menurut 38.408 (Depkes RI, 2010). Rata- rata peristiwa infeksi nosokomial Indonesia lebih kurang $9,1 \%$ menggunakan variasi $6,1 \%-16,0 \%$. Sedangkan di Jawa Timur sendiri angka peristiwa infeksi nosokomial 11,7\% (Depkes RI, 2010).

Mencuci tangan selama aplikasi tindakan keperawatan adalah cara yang paling efektif buat mencegah terjadinya infeksi nosokomial di lingkungan Rumah Sakit. Tenaga kesehatan yg paling rentan dalam penularan infeksi adalah perawat lantaran selama 24 jam mendampingi pasien. Perawat mengambil peran cukup besar dalam memberikan kontribusi terhadap pencegahan infeksi nosokomial. HAIs terjadi karena adanya transmisi mikroba pathogen yang bersumber dari lingkungan rumah sakit merupakan galat satu penyebab bermacam penyakit yg berasal menurut penderita, petugas kesehatan \& lingkungan. (Boyce, 2013).

Kuman penyakit ini dapat hidup dan berkembang biak di lingkungan rumah sakit seperti udara, cairan tubuh pasien, benda-benda medis dan non medis lainnya. Hasil penelitian tentang Hand Hygiene in Hospital: Anatomy of a revolution mengungkapkan untuk menurunkan tingginya kejadian HAIs di Rumah Sakit dan resistensi antimikroba diperlukan pelaksanaan hand hygiene yang baik dan benar. Kepatuhan kebersihan tangan penting untuk upaya pencegahan infeksi yang terjadi di rumah sakit (Della, 2017).

Berdasarkan penelitian yang dilakukan oleh Wijaya (2018) tentang implementasi yang dapat dilakukan untuk meningkatkan kepatuhan five 
Received: 16 June 2021 :: Accepted: 23 June 2021 :: Published: 30 June 2021

moments hand hygiene adalah melalui program pendidikan tentang penelitian terdahulu di beberapa rumah sakit negara tetangga yang menggambarkan efektivitas hand hygiene yang mampu menurunkan penularan infeksi dan menambah peralatan yang terkait dengan pelaksanaan five moments hand hygiene seperti pemberian handrub portable yang bisa dibawa oleh perawat setiap waktu.

Hasil studi pendahuluan di lingkungan masyarakat di kelurahan Lubuk pakam pekan, dengan jumlah remaja 41 orang didapatkan, dari 10 remaja teramati 7 orang tidak melakukan cuci tangan setiap kali selesai berjabat tangan dengan orang asing, dan 3 orang remaja rutin melakukan cuci tangan bila selesai berjabat tangan dengan orang asing. Hasil wawancara pada 7 orang remaja yang tidak melakukan cuci tangan, 7 remaja diantaranya menyatakan karena saat berjabat tangan kondisi tangan orang yang disalamnya dalam keadaan bersih, jadi tidak takut terjadinya infeksi pada remaja yang berjabatan. Hal ini yang membuat perlu dilakukan informasi tentang pentingnya penggunaan hand sanitizer terhadap kepatuhan remaja mencuci tangan didesa lubuk pakam pekan.

\section{Metode}

Jenis Pengabdian ini adalah penelitian pre-eksperimental designs, desain ini belum adalah eksperimen yang sungguh-sungguh lantaran masih terdapat variabel luar yang ikut berpengaruh terhadap terbentuknya variabel dependen. Jadi hasil eksperimen yang merupakan variabel dependen itu bukan semata-mata dipengaruhi sang variabel independen. Bentuk penelitian pre-eksperimental ini dilaksanakan dengan rancangan onegroup pretest-posttest design yang mana pada desain ini terdapat pretest (sebelum diberi perlakuan).

\section{Hasil dan Pembahasan Hasil}

Berdasarkan jumlah remaja yang berdomisili di kelurahan lubuk pakam sebanyak 41 orang. Teknik pengambilan sampel yang digunakan adalah total sampling yaitu teknik keseluruhan untuk menentukan sampel dari populasi.

a. kepatuhan cuci tangan remaja sebelum menggunakan hand sanitizer.

Tabel 3.1 Distribusi Responden Berdasarkan Kepatuhan Cuci Tangan remaja sebelum menggunakan hand sanitizer.

\begin{tabular}{|c|c|c|c|}
\hline $\mathrm{N}$ & Kepatuha & Frekuens & Persenta \\
\hline 0 & $\begin{array}{c}\mathrm{n} \text { cuci } \\
\text { tangan }\end{array}$ & $\mathrm{i}$ & se \\
\hline 1. & Patuh & 8 & 19,5 \\
\hline 2. & $\begin{array}{l}\text { Tidak } \\
\text { patuh }\end{array}$ & 33 & 80,5 \\
\hline & Total & 41 & 100,0 \\
\hline
\end{tabular}

Tabel 3.1 di atas menunjukkan bahwa jumlah remaja berdasarkan Kepatuhan Cuci Tangan sebelum menggunakan hand sanitizer yaitu "patuh" sebanyak 8 orang $(19,5 \%)$, dan jumlah perawat yang "tidak patuh" cuci tangan yaitu sebanyak 33 orang $(80,5 \%)$.
b. kepatuhan cuci tangan remaja sesudah menggunakan hand sanitizer.

Tabel 3.2 Distribusi Responden Berdasarkan Kepatuhan Cuci Tangan remaja sesudah menggunakan hand sanitizer.

\begin{tabular}{cccc}
\hline $\mathrm{N}$ & Kepatuha & Frekuens & Persenta \\
o cuci & $\mathrm{i}$ & se \\
tangan & & \\
1. & Patuh & 30 & 73,2 \\
\hline
\end{tabular}


Received: 16 June 2021 :: Accepted: 23 June 2021 :: Published: 30 June 2021

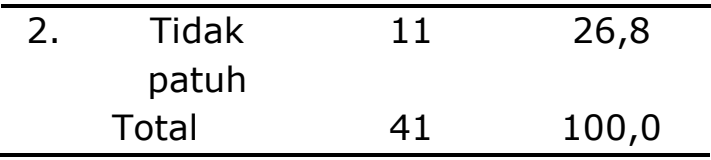

Tabel 3.2 di atas menunjukkan bahwa jumlah remaja berdasarkan Kepatuhan Cuci Tangan sesudah menggunakan hand sanitizer yaitu "patuh" sebanyak 30 orang $(73,2 \%)$, dan jumlah perawat yang "tidak patuh" cuci tangan yaitu sebanyak 11 orang $(26,8 \%)$.

\section{3.penggunaan hand sanitizer terhadap kepatuhan cuci tangan remaja di kelurahan lubuk pakam pekan.}

Tabel $\quad 3.3 \quad$ Distribusi Frekuensi Responden berdasarkan terhadap kepatuhan cuci tangan remaja sebelum dan sesudah penggunaan hand sanitizer.

\begin{tabular}{|c|c|c|c|c|c|c|}
\hline \multirow{3}{*}{$\begin{array}{l}\text { Kepatu } \\
\text { han } \\
\text { cuci } \\
\text { tangan }\end{array}$} & \multicolumn{4}{|c|}{$\begin{array}{l}\text { Penggunaan } \\
\text { hand sanitizer }\end{array}$} & \multirow{2}{*}{\multicolumn{2}{|c|}{ Total }} \\
\hline & \multicolumn{2}{|c|}{ Patuh } & \multicolumn{2}{|c|}{$\begin{array}{l}\text { Tidak } \\
\text { patuh }\end{array}$} & & \\
\hline & $\mathrm{N}$ & $\%$ & $\mathrm{~N}$ & $\%$ & $\mathrm{~N}$ & $\%$ \\
\hline $\begin{array}{c}\text { Sebelu } \\
\text { m } \\
\text { dilakuk } \\
\text { an }\end{array}$ & 8 & $\begin{array}{c}19 \\
5\end{array}$ & $\begin{array}{l}3 \\
3\end{array}$ & $\begin{array}{c}80 \\
5\end{array}$ & $\begin{array}{l}4 \\
1\end{array}$ & $\begin{array}{c}100 \\
\%\end{array}$ \\
\hline Sesuda & 3 & 73 & 1 & 26, & 4 & 100 \\
\hline $\begin{array}{c}\mathrm{h} \\
\text { Dilakuk } \\
\text { an }\end{array}$ & 0 & 2 & 1 & 8 & 1 & $\%$ \\
\hline
\end{tabular}

Tabel 3.3 di atas menunjukkan tabel kepatuhan cuci tangan sebelum penggunaan hand sanitizer didapatkan jumlah "patuh" sebanyak 8 orang $(19,5 \%)$, dibandingkan sesudah penggunaan hand sanitizer "patuh" sebanyak $30(73,2 \%)$, berdasarkan hasil analisis dari uji Paired T-test diperoleh $\mathrm{p}$-value $=0.000<\mathrm{a}=0,05$ dapat disimpulkan bahwa terdapat penggunaan hand sanitizer terhadap kepatuhan cuci tangan pada kelurahan lubuk pakam pekan.

\section{Pembahasan \\ a. kepatuhan cuci tangan remaja sebelum menggunakan hand sanitizer}

Mencuci tangan merupakan
proses yang secara mekanik melepaskan kotoran dan debris dari kulit tangan menggunakan memakai sabun biasa dan air. Cuci tangan juga mampu dilakukan menggunakan agen antiseptik atau antimikroba. Agen antiseptik yang sering dipakai merupakan penggosok tangan (handrub) 4 antiseptik atau handrub yg berbasis alkohol. (Imamah, 2020).

Menurut pengabdian berdasarkan Riu, 2021, menyatakan bahwa Ada Hubungan Perilaku menggunakan Kepatuhan Perawat melakukan hand hygiene dan terdapat Hubungan ketersediaan fasilitas menggunakan kepatuhan perawat melakukan hand hygiene pada Ruang Rawat Inap Bedah Flamboyan Rs. TK. II Robert Wolter Mongisidi Manado, menggunakan nilai nilai signifikansi atau sig (2-Tailed) sebanyak $0,003<p 0,05$ menggunakan nilai correlation coeficient sebanyak 0,730.

Penggunaan hand sanitizer masih kurang digunakan oleh remaja dikarenakan remaja masih banyak yang menganggap bahwa lebih enak bila melakukan cuci tangan dengan menggunakan sabun dan air yang mengalir dibandingkan dengan menggunakan hand sanitizer. Karena kesannya lengket ditangan dan panas.

\section{b. kepatuhan cuci tangan remaja sesudah menggunakan hand sanitizer}

Mencuci tangan dengan menggunaan handrub antiseptik buat tangan yg higienis lebih efektif 
Received: 16 June 2021 :: Accepted: 23 June 2021 :: Published: 30 June 2021

membunuh flora residen \& flora transiden daripada mencuci tangan menggunakan sabun antiseptic atau sabun biasa \& air. Mencuci tangan adalah kondisi primer yg wajib dipenuhi sebelum melakukan tindakan keperawatan misalnya: memasang infus, mengambil spesimen. Infeksi yg pada akibatkan menurut pemberian pelayanan kesehatan atau terjadi dalam fasilitas pelayanan kesehatan. (Perry \& Potter, 2000).

Sedangkan pengabdian menurut Basuki, 2016 menyatakan bahwa output hubungan antara ke 2 variabel merupakan 0,579. Sedangkan nomor sig.(2-tailed) merupakan 0,007 masih lebih kecil menurut batas kritis. $a=0,005$. Berarti Ho pada tolak, merupakan terdapat interaksi antara kepatuhan perawat pada melakukan cuci tangan enam langkah 5 momen menggunakan insiden phlebitis pada RSUD dr. Wahidin Sudiro Husodo Kota Mojokerto.

Mencuci tangan menggunakan hand sanitizer sekarang sangat di anjurkan untuk dilakukan bagi semua orang dikarenakan lebih mempermudah, praktis dan tidak kesulitan untuk mencari air.

\section{c. Penggunaan hand sanitizer sebelum dan sesudah terhadap kepatuhan cuci tangan}

Berdasarkan hasil analisis dari Uji Paired T-test diperoleh $\mathrm{p}$-value $=0.000$ $<a=0,05$, maka hipotesis penelitian diterima, sebagai akibatnya bisa disimpulkan bahwa masih ada penggunaan hand sanitizer terhadap kepatuhan cuci tangan remaja pada kelurahan lubuk pakam pekan. Dalam meningkatkan kepatuhan melakukan cuci tangan dengan menggunakan hand sanitizer dapat mencegah penularan pathogen, mikroorganisme masuk kedalam tubuh yang dapat mengakibatkan infeksi silang. Oelh karenanya penggunaan hand sanitizer sangat di anjurkan untuk melakukan cuci tangan secara cepat, ekonomis, dan mudah dilakukan tanpa mencari air yang mengalir.

\section{Kesimpulan}

Remaja diharapkan dapat melakukan cuci tangan menggunakan hand sanitizer secara teratur saat sudah kontak langsung dengan orang asing untuk mencegah terjadikan infeksi silang dari orang lain ke tubuh remaja yang ada di kelurahan lubuk pakam pekan guna mencegah menyebarkan virus covid 19 di daerah mereka tinggal.

\section{Ucapan Terima Kasih}

Pengabdi menyampaikan

ucapan terima kasih kepada:

a. Lembaga Seminardan Pengabdian Kepada Masyarakat (LPPM) Institut Kesehatan Medistra Lubuk Pakam.

b. Direktur Rumah Sakit Granmed Lubuk Pakam

\section{Daftar Pustaka}

Boyce JM, Pittet D (2013); Healthcare infection control Practices advisorycommittee;HICPAC/SHEA /APIC/IDSA Hand hygiene Task Force. Guideline for hand hygiene in Health-Care settings.

Depkes RI. 2010. Pedoman Manajerial Pencegahan Dan Pengendalian Infeksi Di Rumah Sakit Dan Fasilitas Kesehatan Lainnya, Jakarta. 2015. Program Pencegahan dan Pengendalian Infeksi Nosokomial Merupakan Unsur Patient Safty. Jakarta.

Della Rindayantika Sari, (2017), Hubungan Pengetahuan Petugas Kesehatan Dengan Perilaku Fivemoment For hand Hygiene pada Rumah Sakit PKU 


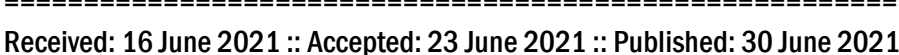

Muhammadiyah

Gamping.

Universitas'Aisyiyah Yogyakarta.

Fauztihana, et all. (2020). Keefektifan

Penggunaan Hand Sanitizer

Sebagai Pengganti Sabun Dan Air

Dalam Cuci Tangan Selama

Pandemi Covid-19.

Imamah, (2020). Gambaran Cuci Tangan Perawat Dengan Menggunakan Hand Sanitizer Pada Saat Pemasangan Infus Di Ruang Flamboyan Rsud Abdul Wahab Sjahranie Samarinda. Jurnal Kesehatan Masyarakat Mulawarman Vol.2, No.1 Juli 2020 E-Issn : 2686-3601.

Wijaya. (2018). Pelaksanaan Keselamatan Pasien Melalui Lima Momen Cuci Tangan Sebagai Perlindungan Hak Pasien. SOEPRA Jurnal Hukum Kesehatan ISSN: 2548-818X (media online). Vol. 4 | No. 1 | Juni 2018. 